\title{
Preface to the English-Language Edition
}

With its Stendhalian title, this book on homosexuals in France since 1968, now being published in English, may give its anglophone readers the impression of being a little too French. English-speaking readers will probably be surprised that the United States, the standard-bearer of the global homosexual cause, is so rarely mentioned. When it is mentioned, in the margins of the book, they will certainly judge that the little information given is too fragmentary. And this is true. Finally, the references that are cited, the debates that are mentioned, and the positions that are supported in this book will appear a bit baroque, perhaps even byzantine, outside their French context. It is thus with some uneasiness that I see this book appear in English.

There is a second reason for this apprehension: I wrote, between the ages of twenty-three and twenty-seven, what is a book of collective but also individual emancipation, and I published it when I was twenty-eight years old, at the end of a militant and political period in my life.' It was therefore a book of my youth, an apprenticeship, and-dare I say it?-a "coming out" book. Overall, if I had it to write today, I would do it somewhat differently, with more distance and nuance, and with less passion. I would probably modify the epilogue in the light of concrete political confrontations and my recent experience in a situation of political responsibility with respect to the debates on the Pacte Civil de Solidarité [Civil Pact of Joint Responsibility], or PACS. ${ }^{2}$

In spite of these worries, I insisted, out of concern for authenticity, that the published English version of my book be identical ${ }^{3}$ to the French edition, even at the risk of causing some misunderstandings about me or of giving-wrongly, I think - the impression that France is a truly backward country in terms of its social mores.

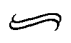

The book, then, is French in more ways than one. Should it be seen as part of our penchant, so often criticized, for Franco-French navel-gazing? Do the antagonistic positions mentioned in this book have meaning only in the national context of France? Is there a French specificity that in itself would justify this treatment of the "French exception"?

I do not think so. It is up to readers to evaluate whether this history differs no- 
ticeably from their own history in the country where they live. For myself, I will speak only of a French singularity. Above all, I believe it is necessary to remind readers that I neither intend to give an internationally valid interpretation of the history of homosexual men and women nor claim to draw a universal lesson about the best possible approach to facilitating the integration of homosexuals worldwide. Most important, I do not claim to make any judgments about the overall attitude that homosexual militants ought to have taken during the early years of the AIDS epidemic.

\section{A FRENCH SINGULARITY}

This book's only ambition is to offer a reading of the history of homosexuals in France since 1968. To be sure, it is the first such book (in France there has been no book of this kind before), but it will not be the only one (since this history will also be written, I hope, by other historians and will be elaborated, completed, and reevaluated in books that have yet to appear).

Readers are invited, then, to immerse themselves in the history of another country-it is up to them to decide whether this history is slightly or vastly different from their own-and, by considering the elements specific to their own country, to assess the political power structure that exists in that other country. I hope they will then find this book to be both of documentary interest and a basis for comparison-a small thing, and also a great deal.

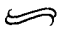

Since The Pink and the Black appeared in France (in April 1996), two issuespublic recognition of homosexuality, and the fight against AIDS-have undergone an evolution. ${ }^{4}$ To put it rather cavalierly, and just as succinctly, I feel that the major hypotheses offered in this book have been confirmed in the last three years.

In this preface, then, I propose to return to these various evolutions and to go into more detail about the most recent context of the subject in France, but also to bring some perspective to two major debates provoked by my book: first, the debate about the attitude of "denial" on the part of gay activists in France, between 1982 and 1985, in the face of the AIDS epidemic; and, second, the more general debate about the advisability of building a political community of homosexuals.

The book discusses many other issues - for example, the persistent homophobia in France (on the religious and political far right); the discovery, by Luc Montagnier's team in 1984-85, of the retrovirus named HIV; "homosexual culture" in the country of Marcel Proust and Jean Genet; the role played by François Mitterrand in suppressing homosexual discrimination in 1981-83; and the major role played by female homosexuality within the history of the women's movement. Nevertheless, the debates about AIDS and about communitarianism have been the most important ones, partly because my book marked a departure from the usual language of "homosexual spokespersons." It is to these debates, then, that I wish to 
return, even though I cannot devote to them all the space that is necessary. Still, I feel that the book sets these two debates out clearly enough for a non-French reader to understand their ins and outs. Therefore, with some regret, I will limit myself to retracing their main outlines.

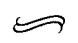

With respect to the first debate, in chapters 10 and 11 I examine the reaction in homosexual circles between 1981 and 1985 to the appearance of AIDS. All my questions are directed toward a single inquiry: Why, during those years, but especially between 1983 and 1985, were homosexual militants and the owners of commercial establishments slow to react to the disease? Of course, I take into account the context of the time (the lack of medical knowledge, the lack of visibility of the "epidemic") and the reactions that surfaced in those years (the renewed stigma attached to homosexuals by means of a "gay cancer"; the birth, 1984, of Aides, an AIDS organization; the political errors made in $1984-85$, under the government of Laurent Fabius).

The issue of "denial" of AIDS in French gay circles between 1982 and 1985 is not unimportant. On the contrary, I found it to be essential, "the darkest chapter of that dark history" (to quote Hannah Arendt). The issue had to be raised, discussed, and commented on, even if this "wait and see" attitude (a term I would now choose over "denial") remains a fundamentally embarrassing problem. This book will make clear how things developed in France.

One further note: at no point in my book do I situate myself inside a logic of culpability; rather, I seek an explanation. Was an explanation possible, given that these were events and an epoch that I did not personally live through? Yes, of course: otherwise, "neither the administration of justice nor the writing of history would ever be possible." I therefore attempt to understand the past—and to judge it—in order to illuminate the present and, perhaps, attempt to get a better grasp of the future.

From this perspective, the decision handed down by the Cour de Justice de la République on March 9, 1999, exonerating former prime minister Laurent Fabius in the contaminated-blood scandal, tends to complement my own analysis and confirm its relevance: the context did make the dangers of the epidemic "indiscernible." On the whole (and the book details all these elements), political leaders, physicians, and even hemophilia organizations and drug treatment centers did no better than homosexual militants at assessing the scope of the epidemic in France between 1983 and 1985. That's the way it is.

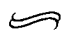

I now come to the second debate: the one about communitarianism. This debate, considered primarily in the book's epilogue, has been a recurring one in France since the early 1990 s (and in the United States as well, it seems to me, but earlier). France-through the so-called Islamic head-scarf affair, the re-Islam- 
ization of certain outlying districts, and the move toward political parity for women-has become tuned in on a daily basis to issues surrounding the notions of "republic," "nation," "identity," and so on, and to the often passionate confrontations that these issues entail.

Let me say, briefly, that I take a line both very moderate and, to tell the truth, rather unoriginal (for France). Of course, I am probably the first in my country to have applied the terms of this debate to homosexuals and the fight against AIDS, but my position is completely classic in a country that never tires of commemorating the Revolution of 1789 , the Republic of 1875 , and the Constitution of 1958 . In fact, I feel as far removed from a nervous (and stereotypically French) republicanism as from an extremist communitarianism. I have attempted to show, with equal vigor, why it was necessary to reject the arguments of those advocating the "right to difference" as well as the arguments of those who, in the name of an idealized and largely make-believe French republic, reject diversity and are altogether too satisfied with a "right to nonexistence"; why it was necessary to reject a blind communitarianism as well as an incantatory, nervous republicanism that denies social realities and different lifestyles; and why it was necessary to reject the dictatorship of the majority as well as the dictatorship of minorities.

In reality, there is something rather polarized and certainly artificial about this debate, since no one in France has ever feared or even claimed that French gays were going to leave the republic, transform the Marais district into the State of Sodom, opt for separatism, or mint money. And is it necessary to point out how much I like a number of the gay bars in the Marais, and that I frequent them regularly?

This is why I gave my epilogue the title "A Dubious Communitarianism." Nevertheless, it seemed to me that certain attitudes and kinds of behavior, especially during the early years of the AIDS epidemic, had to be analyzed and, as necessary, criticized.

Are my positions close to those of the conservative camp? A few radical gay militants and communitarians have claimed that they are. ${ }^{8}$ It seems to me that a response to this criticism can be found simply in the reading of this book.

I agree with my critics on one point, however: the persistence of "official" homophobia. Over the last few months, in fact, during the debate on the PACS legislation-even though this legislation is cautious and moderate-we have seen a few rightist members of the National Assembly refuse, in profoundly discriminatory ways, any legal recognition to homosexual couples. A few (especially one, Christine Boutin, a fundamentalist Catholic, antiabortion militant, and religious fanatic) have even distinguished themselves by truly hateful and violent homophobia. Hence, for them, homosexuals, by supporting the PACS legislation, are threatening the family, marriage, filiation, the country's finances, public order, and who knows what else- and all in the name of "the republic"!

It will be clear that I do not identify in any way with such arguments, which distort the idea of the republic and, under cover of unconditional support for the French republican model of integration, thinly veil not just a desire to prohibit 
manifestations of collective identity and eradicate diversity but also what must, after all, be called by its name: homophobia. These "republican" arguments also overlook the specificity of the French model of integration, which guarantees every individual the right to choose an affiliation without being confined to it.

This is why, in the epilogue of my book, I insisted on the necessity of recognizing homosexuals, why I have fought for equal rights for unmarried couples (whether heterosexual or homosexual), and why I do not confuse the "right to indifference" with the "right to ignorance" that is so often used against homosexuals as a way of not recognizing their rights.

Thus it seems to me that the PACS legislation is directly in line with my book's epilogue. The PACS legislation is universalist because it is applicable to all unmarried couples (heterosexual or not) and rejects the conferring of a specific status on homosexuals. It is modern because it is not encumbered by the constraints or symbols specific to the unions of another era. It is generous because it proposes a number of concrete rights (economic and social rights, inheritance rights, rights for couples who are government workers). Finally, it is cautious because it does not raise questions involving next of kin or adoption, and it avoids taking on or provoking heterosexuals by tampering with marriage.'

On the whole, the aim of the PACS legislation, and my goal in the epilogue of the book, is integration, normality, and indifference. These words are not very appealing by comparison with the flamboyant terms "marginality," "specificity," and "community," but they nevertheless correspond to an essential pursuit for French homosexuals: to find a place in society—a comfortable place—and hence finally to become adults.

To be "like other people," to live as mature and free people, requires seeking a harmonious way of living together with our differences. It is a difficult quest, of course, but also a necessary one, and it inevitably entails rejecting the temptations of uniformization and of a fixed identity. It is at this price that we will be able to invent a new model: a modern state, hospitable to "the other" and protective of individuals, of their similarities as well as their differences.

In the last part of this preface, I would like to deal briefly and directly with a serious question raised by my book's publication, a question that seems intrinsically linked to the objective of maturity that I wish gays to be able to achieve: How should a homosexual situate himself in relation to "his" community, and what type of solidarity should he demonstrate with "his" "people"?

Contrary to what certain militants sometimes believe, the true defender of homosexuals is not, it seems to me, the one who, for demagogic, political, or commercial reasons, flatters "his" community, but the one who is sadder than anyone else when he is reminded of the errors of the past and of the many who have died. This is why it is up to him to "speak," to "tell," since even at this stage, it seems to me, no one should be displaying unconditional solidarity with his people.

Moreover, in the course of the debates over my book, the issue of "solidarity" has become conflated with an opposition between two political notions (not right 
versus left, but reformist left versus radical left), and especially with a certain aspect of the generation gap. It has been more than thirty years since 1968. Those who participated in the movements for "sexual liberation" have preserved a certain indulgence for their bold acts of yesteryear, and they continue to commemorate the utopia that most certainly was inherent in these acts. The late 1960 s survive in the form of nostalgia for a paradise lost, even though no one has risked predicting what this utopia might have looked like. In France, this nostalgia feeds our daily fantasies by perpetuating the myths of "May": the right to plural desires, sexual indetermination, "desiring machines" (along with their contradictions), an overinvestment in the political realm, the rejection of half-measures, erasure of the separation between public and private.

Then along comes a book that casts doubt on the radicalism and love of provocation that spiced up a whole generation's youth (the AIDS epidemic having become, in the meantime, that generation's swan song): it is easy to understand why people would find the self-criticism difficult to carry out. And then the French left supports the proposal for the Pacte Civil de Solidarité, modest in its way and yet reformist, supportive of a certain "banalization" of the stable homosexual couple, respectful of the rights and demands of heterosexuals: it is easy to see the uneasiness that such an event might inspire in the far left, which even today is too often content to believe that having multiple partners is the only fulfilling form of sexuality, that revolutionary acts are the basis of political action, and that provocation and subversion are the only public discourse possible for the militant homosexual.

But the contemporary world has changed a great deal. Condemned to live in this world, deprived of the horizon of a bright new tomorrow, reminded of our finitude-reminded, that is, of the future's unpredictability-we need to rethink our possibilities for happiness.

In a period when sexual life is still marked by AIDS, when the search for homosexual autonomy is expressed only sporadically in the critical activism of student movements and antiestablishment "fronts," it is time to reestablish ties with a less impossible happiness. To achieve it (since the dynamic of generational conflict is a chronic illness), must we oppose our predecessors absolutely, support the gay couple, and criticize the gay community? No. But we must demand a new right to a "historical" reading (we need to write history, not "our" history) and a right to take stock of homosexual liberation and the fight against AIDS. On the whole, to apprehend the past and judge it, a "minority" must reach adulthood (must reach, in some sense, its "majority").

This is why a gay man, with a favorable bias and a show of courtesy, but with an equal measure of lucidity and, at times, even a certain intransigence, when necessary, must criticize the gay community, just as he must pay tribute to its many battles and demonstrations of courage.

Paris, March 1999 
THE PINK AND THE BLACK 
